\title{
PREVALENCE OF RISK FACTORS OF CARDIOMETABOLIC COMPLICATIONS IN LATENT AUTOIMMUNE DIABETES IN ADULTS
}

\section{I.O. Tsaryk, N.V. Pashkovska, O.I. Ilashchuk}

Bukovinian State Medical University, Chernivtsi, Ukraine

Key words: diabetes mellitus, latent autoimmune diabetes in adults, cardiometabolic complications, metabolic syndrome, phenotypes.

Bukovinian Medical Herald. V.25, № 2 (98). P. 123-127.

DOI: $10.24061 / 2413-$ 0737.XXV.2.98.2021.20

E-mail: irynatsaryk13@ gmail.com, nvpashkovska@gmail. com
The aim of the study. To determine the prevalence of risk factors for cardiometabolic complications in latent autoimmune diabetes in adults compared to other types of diabetes depending on the phenotype of the disease.

Materials and methods. A comprehensive examination of 106 patients with diabetes mellitus: 45 (main group) with latent autoimmune diabetes in adults (LADA), 26 - with type 1 diabetes mellitus (T1DM), 35 - with type 2 diabetes mellitus (T2DM). Complaints, anamnesis data, objective examination, results of general clinical, laboratory researches, indicators of carbohydrate metabolism, titers of antibodies to glutamic acid decarboxylase were evaluated.

Results. The prevalence of metabolic syndrome (MS) in LADA was 51\% and was significantly higher than in T1DM (19\%), but was lower compared with T2DM (94\%). The highest incidence of MS was found in patients with the LADA2 phenotype (87\%). Of particular note is the fact that this figure was close to that in T2DM. At the same time in LADA1 the incidence of MS was lower (36\%), but twice as high as in T1DM. In addition to hyperglycemia, abdominal obesity (62\% of patients), hypertension (78\%) and dyslipidemia (56\%) were commonly reported in $L A D A$.

Conclusions. The prevalence of metabolic syndrome as a complex of cardiometabolic risk factors in LADA differs from that in classical types of diabetes, which requires a differential approach to their management.

\section{ПОШИРЕНІСТЬ ЧИННИКІВ РИЗИКУ КАРДІОМЕТАБОЛІЧНИХ УСКЛАДНЕНЬ ПРИ ЛАТЕНТНОМУ АВТОІМУННОМУ ДІАБЕТІ ДОРОСЛИХ}

\section{І.О. Царик, Н.В. Пашковська, О.І. Ілащук}

Буковинський державний медичний університет, м. Чернівці, Україна

\author{
Ключові слова: \\ иукровий діабет, \\ латентний \\ автоімунний \\ діабет дорослих, \\ кардіометаболічні \\ ускладнення, \\ метаболічний синдром, \\ фенотипи.
}

Буковинський медичний вісник. Т.25, № 2 (98). C. 123-127.
Мета роботи - з'ясувати поширеність чинників ризику кардіометаболічних ускладнень при латентному автоімунному діабеті дорослих порівняно $з$ іншими типами иукрового діабету залежно від фенотипу захворювання. Матеріал і методи. Проведене комплексне обстеження 106 пацієнтів із иукровим діабетом: 45 (основна група) з латентним автоімунним діабетом дорослих (LADA), 26 - із иукровим діабетом 1-го типу (ЦД1), 35 - із иукровим діабетом 2-го типу (ЦД2). Оиінювали скарги, дані анамнезу, об 'єктивного обстеження, результати загальноклінічних, лабораторних досліджень, показників вуглеводного обміну, титри антитіл до декарбоксилази глутамінової кислоти.

Результати. Поширеність MC при LADA становила 51\% і значно перевищувала таку при ЦД1 (19\%), але була меншою порівняно із ЦД2 (94\%). Найбільша частота MC виявлена у пащієнтів із фенотипом LADA2 (87\%). На особливу увагу заслуговує той факт, щз ичей показник наближався до такого при ЦД типу 2. Водночас при LADA1 частота MC була меншою (36\%), але удвічі перевищувала відповідну при ЦД1. Окрім гіперглікемії, при LADA часто реєструвались абдомінальне ожиріння (у 62\% пацієнтів), артеріальна гіпертензія (у 78\% осіб) та дисліпідемія (у 56\% осіб). 
Висновки. Поширеність метаболічного синдрому, як комплексу факторів кардіометаболічного ризику при LADA, відрізняється від такого при класичних типах ЦД, щзо потребує диференщійного підходу до їх менеджменту.

\title{
РАСПРОСТРАНЕННОСТЬ ФАКТОРОВ РИСКА КАРДИОМЕТАБОЛИЧЕСКИХ ОСЛОЖНЕНИЙ ПРИ ЛАТЕНТНОМ АУТОИММУННОМ ДИАБЕТЕ ВЗРОСЛЫХ
}

\author{
И.А. Царик, Н.В. Пашковская, О.И. Илащук
}

Ключевые слова:

сахарный диабет, латентный

аутоиммунный

диабет взросльх,

кардиометаболические

осложнения,

метаболический

синдром, фенотипь.

Буковинский медицинский вестник. T.25, № 2 (98). C.123-127.

\begin{abstract}
Цель работы - Выяснить распространенность факторов риска кардиометаболических осложнений при латентном аутоиммунном диабете взрослых по сравнению с другими типами сахарного диабета в зависимости от фенотипа заболевания.

Материал и методы. Проведенно комплексное обследование 106 пациентов с сахарным диабетом: 45 (основная группа) с латентным аутоиммунным диабетом взросльхх (LADA), 26 - с сахарным диабетом 1-го типа (CД1), 35 - с сахарным диабетом 2-го типа (СД2). Оиенивали жалобы, данные аналнеза, объективного обследования, результаты общеклинических, лабораторных исследований, показателей углеводного обмена, титры антител к декарбоксилазе глутаминовой кислоты.

Результаты. Распространенность MC при LADA составляла 51\% и значительно превышала таковую при СД1 (19\%), но была меньше по сравнению с СД2 (94\%). Наибольшая частота МС была обнаружена у пациентов с фенотипом LADA2 (87\%). Особого внимания заслужсивает тот факт, что этот показатель приближался к такому при СД2. В то же время при LADA1 частота MC была меньше (36\%), но вдвое превышала соответствуюшую при СД1. Кроме гипергликемии, при LADA часто регистрировались абдоминальное ожирение (у 62\% пациентов), артериальная гипертензия (у 78\% лии) и дислипидемия (у 56\% человек).

Выводы. Распространенность метаболического синдрома, как комплекса факторов кардиометаболического риска при LADA, отличается от такового при классических типах СД, требует дифференциального подхода к их менеджменту.
\end{abstract}

Introduction. Diabetes mellitus (DM) has become a global epidemic in recent decades resulting in huge human, social and economic losses. Currently, more than 463 million adult patients with diabetes are registered in the world, however, according to experts, the actual figure is much higher and, in the long run, will grow steadily [1].

The research results in recent years indicate a significant heterogeneity of diabetes with various genetically determined phenotypes of the disease, which often do not fit into the picture of classical types of diabetes. Given this, more and more scientists point to the need to revise the classification of diabetes and create personalized approaches to its management [2]. Among such "nonclassical" variants of diabetes, the leading place is occupied by latent autoimmune diabetes in adults (LADA) - a form of the disease that has symptoms of both type 1 diabetes (T1DM) and type 2 diabetes (T2DM), which is why it is also called diabetes mellitus 1,5 type.

LADA has genetic features of both T1DM and T2DM, which determines the significant variability of the degree of $\beta$-cell destruction, insulin resistance, autoimmunity and other pathogenetic links [3]. At the same time, less activity of the autoimmune process determines a more gradual lymphoid infiltration with progressive $\beta$-cell death than in classical T1DM, which causes a late onset and "mild" course of the disease more similar to T2DM [4].

The urgency of the problem of this variant of diabetes is evidenced by the fact that recently the American Diabetes Association (ADA), for the first time in many years, decided to change the classification of diabetes to include LADA, which was still not officially recognized [5].

The prevalence of LADA in the world is relatively high and, according to various data, ranges from $4 \%$ to $14 \%$ depending on the population and research methodology and is the highest among the population of European countries $[6,7]$. In particular, a large-scale study of UKPDS25 found elevated titers of GADA and / or antibodies to islet cell protein antigen and / or antigens phosphine phosphatase (IA-2) in almost one in ten of 3,672 patients with diabetes aged 25 to 65 years [8].

Despite the significant prevalence of LADA, there are currently no official criteria for diagnosing this disease. In 
Original research

general, the diagnosis is established in the presence of three main components: the onset in adulthood, the presence of antibodies to islet antigens as a marker of autoimmune activity and insulin independence for at least 6 months from the onset of the disease [9]. It should also be noted that no official guidelines for the management of patients with this type of diabetes have been developed yet.

This year, for the first time in the more than thirtyyear history of LADA, an international expert panel was held to build consensus on approaches to insulin therapy in LADA depending on the degree of C-peptide insulin deficiency [10]. At the same time, the question of the need for pathogenetic treatment to enhance insulin action is still unclear as aspects of the role of pathogenetic mechanisms of DM in the development of LADA, primarily insulin resistance, are currently insufficiently disclosed. Due to the fact that this variant of diabetes is similar not only to T1DM, but also T2DM, the risk of metabolic complications in this category of patients becomes particularly relevant.

Today the current results of research in this area are few and far between. Thus, two large Scandinavian population studies, the Swedish case-control study and the Norwegian HUNT Study, have shown that overweight and obesity are associated with an increased risk of developing LADA [11]. There is also evidence that body weight and insulin resistance in LADA are associated with autoimmunity and are lower in patients with high titers of antibodies to islet antigens [12].

According to the results of a study by the same authors, metabolic syndrome is registered in more than $40 \%$ of patients with LADA [13], but other scientists have not found an increase in the frequency of metabolic syndrome in LADA [14]. This difference in data is obviously related to both population-determined and genetically determined differences and lifestyle features. Also, the reasons can be various methodological approaches and phenotypic inhomogeneity of LADA with differences of the dominance of signs of T1DM and T2DM.

In view of the above, it is important to study the prevalence of cardiometabolic complications as components of the metabolic syndrome (MS) in patients with LADA depending on the phenotype of the underlying disease.

The aim of the study. To determine the prevalence of risk factors of cardiometabolic complications in latent autoimmune diabetes in adults compared to other types of diabetes depending on the phenotype of the disease.

Materials and methods. Examination of 106 patients with DM was performed (mean age $-54.7 \pm 8.59$ years, mean duration of diabetes $-7.9 \pm 4.31$ years). Among patients with diabetes 45 were diagnosed with LADA, 26 with T1DM and 35 with T2DM. Complaints, anamnesis data, objective examination, results of general clinical laboratory tests and carbohydrate metabolism indicators were evaluated (plasma glucose, glycated hemoglobin, C-peptide, HOMA-IR index), titers of antibodies to glutamic acid decarboxylase (antiGAD).

Patients with LADA according to the main phenotypes were divided into 2 groups: LADA1 (22 individuals), which is more similar to T1DM with high titers $(\geq 180 \mathrm{U} / \mathrm{ml})$ to antiGAD and LADA2 (23 individuals) with a predominance of T2DM and low antibody titers (18-180 U / ml) [15]. In establishing LADA were guided by the recommendations of the Immunology of Diabetes Society [16]. MS as a combination of cardiometabolic risk factors was established on the basis of the criteria of the International Diabetes Federation (IDF) in 2005 with the 2009 modification.

Results and discussion. The prevalence of MS in LADA was $51 \%$ which was significantly higher than in T1DM (19\%) but was lower compared with T2DM (94\%). The highest incidence of MS was found in patients with LADA2 phenotype (87\%). Of particular note is the fact that this figure was close to that in T2DM. At the same time, in LADA1 the incidence of MS was lower (36\%) but twice as high as in T1DM. In addition to hyperglycemia, abdominal obesity (62\% of patients), hypertension (78\%), and dyslipidemia (56\%) were commonly reported in LADA.

BMI in patients with LADA was $25.5 \mathrm{~kg} / \mathrm{m} 2$ and was significantly lower by $20.4 \%$ ( $<<0.001)$ against the group of T2DM $(32.1 \mathrm{~kg} / \mathrm{m} 2)$ but changes in BMI relative to the group of T1DM $(B M I=24.0 \mathrm{~kg} / \mathrm{m} 2)$ were unreliable. Analysis of the values of waist circumference (WC) in men showed the following pattern: a probable increase in patients with LADA $(97.3 \mathrm{~cm})$ relative to the group of T1DM $(85.8 \mathrm{~cm})$ by $13.4 \%(\mathrm{P}<0.01)$, while WC compared to people with T2DM was significantly lower by $13.4 \%$ (P $<0.01)$ and was $112.5 \mathrm{~cm}$. Changes in WC in women were similar: a probable increase in patients with LADA $(85.9$ $\mathrm{cm})$ compared to people with T1DM $(74.5 \mathrm{~cm})$ by $15.3 \%$ (P $<0.01)$ and in comparison with the T2DM group the waist circumference was $96.3 \mathrm{~cm}$ and was significantly lower by $10.8 \%(\mathrm{P}<0.05)$.

Changes in systolic blood pressure (SBP) in patients with LADA did not differ significantly compared with T1DM and T2DM: $133.8 \mathrm{~mm} \mathrm{Hg}$ when LADA compared with $127.9 \mathrm{~mm} \mathrm{Hg}$ with T1DM and $136.5 \mathrm{~mm} \mathrm{Hg}$ in T2DM. Features of the data of diastolic blood pressure (DBP) were similar: LADA - $83.1 \mathrm{~mm} \mathrm{Hg}$, T1DM - 79.8 mm Hg, T2DM - $83.0 \mathrm{~mm} \mathrm{Hg}$. Art. The changes were insignificant.

When comparing the results of physical examination of patients with different LADA phenotypes, it was found that BMI was highest in patients with LADA2 $(22.8 \%$ against the LADA1 group $(\mathrm{P}<0.001)$ ), but changes in this indicator relative to the LADA1 group were insignificant. Analysis of waist circumflex (WC) data in men showed the following pattern: a probable increase in the rate of patients with LADA2 compared with LADA1 by $13.3 \%(\mathrm{P}<0.05)$. Changes in WC in women were similar: the largest value in people with LADA2 - a likely increase of $26.6 \%$ compared with the group LADA1 $(\mathrm{P}<0.001)$. SBP changes in patients with different types of LADA did not differ significantly between the LADA1 and LADA2 groups. The features of the DBP data were as follows: there was a probable increase of $7.94 \%$ compared with LADA1 $(\mathrm{P}<0.05)$.

No significant changes in fasting glucose and $\mathrm{HbA} 1 \mathrm{c}$ in LADA compared to classic types of diabetes were found in contrast to the level of C-peptide which in patients with 
LADA was $1.4 \mathrm{ng} / \mathrm{ml}$ and was probably lower by $62.7 \%$ compared with T2DM $(\mathrm{P}<0.001)$ and significantly higher by $85 \%$ against those with T1DM $(\mathrm{P}<0.01)$. Insulin levels in patients with LADA were significantly lower $(60.3 \%)$ compared with T2DM $(\mathrm{P}<0.001)$. The HOMA-IR index in LADA was significantly lower $(56.8 \%)$ compared with T2DM $(\mathrm{P}<0.001)$. Analysis of the Caro-IR index showed higher values for T2DM $(2.8$ times $)(\mathrm{P}<0.05)$. In the analysis of changes in carbohydrate metabolism in patients with LADA depending on the phenotype, no probable changes were detected.

Changes in C-peptide level in patients with different phenotypes of LADA were as follows: a probable decrease in LADA1 levels by $51.9 \%$ relative to LADA2 $(\mathrm{P}<0.01)$. Insulin levels were $93.4 \%$ higher in patients with LADA2 compared with LADA1 $(\mathrm{P}<0.01)$. The HOMA-IR index in LADA2 was the largest: there was a probable increase of 2 times compared to LADA1 $(\mathrm{P}<0.01)$ indicating a high degree of insulin resistance. At the same time, the analysis of the Caro-IR index did not show probable changes in the comparison of different LADA phenotypes.

Regarding changes in lipid metabolism in patients with LADA in comparison with classical forms of diabetes: LDL levels were significantly higher by $21.5 \%$ compared with T1DM $(\mathrm{P}<0.001)$ and significantly lower (by $21.7 \%)$ compared to persons with T2DM $(\mathrm{P}<0.001)$. There was a statistically significant decrease (by $15.8 \%$ ) in the level of HDL in patients with LADA relative to the group of T2DM ( $\mathrm{P}<0.01$ ), while exceeding by $28.1 \%$ the corresponding indicator in the group of persons with T2DM $(\mathrm{P}<0.001)$. The content of LC in patients with LADA was significantly higher by $14.4 \%$ compared with T1DM $(\mathrm{P}<0.01)$ and did not differ significantly from the group of patients with T2DM. The level of TG in LADA was significantly lower by $33.7 \%$ compared to the group of T2DM $(\mathrm{P}<0.01)$ and practically did not change relative to persons with T1DM. Changes in integrated atherogenic index (AI) in patients with LADA were as follows: a probable increase of $62.1 \%$ relative to persons with T1DM $(\mathrm{P}<0.001)$ and a significant decrease of $24.0 \%$ against the same rate in T2DM $(\mathrm{P}<0.05)$.

Changes in similar indicators in different phenotypes of LADA were as follows: LDL levels were highest in LADA2: $68.6 \%$ relative to LADA1 $(\mathrm{P}<0.001)$; HDL did not significantly differ between different phenotypes. IA was the highest in LADA2: a significant increase of 51.8\% compared with LADA1 $(\mathrm{P}<0.001)$.

In patients with LADA direct correlations were found between antiGAD titers and the HOMA-IR index $(\mathrm{r}=0.392$, $\mathrm{p}<0.05), \operatorname{HbA} 1 \mathrm{c}(\mathrm{r}=0.511, \mathrm{p}<0.05), \mathrm{CA}$ and OT $(\mathrm{r}=$ $-0.326, p<0,05)$, IA and WC $(r=-0,455, p<0,05)$, inverse between antiGAD and BMI titers $(r=-0,382, p<0,05)$ and WC $(r=-0,423, p<0.05)$, antiGAD titers and C-peptide levels $(r=-0.634, p<0.05)$, while no significant associations were found between antiGAD titers, fasting glycemia and Caro-IR index.

Thus, cardiometabolic complications are a common symptom complex in LADA and occur in every second patient and in the LADA2 phenotype their prevalence is close to that in T2DM. The components of the metabolic syndrome by the degree of manifestation of pathological changes occupy intermediate positions between classical T1DM and T2DM and are the most significant in the LADA2 phenotype depending on the titers of antiGAD and the degree of insulin resistance.

In view of this, despite the fact that LADA belongs to the current classification to T1DM, patients with LADA2 phenotype are at high cardiometabolic risk and need appropriate screening, treatment and prevention of cardiovascular disease as individuals with T2DM.

Conclusions

1. Risk factors for cardiometabolic complications are found in every second patient with latent autoimmune diabetes in adults.

2. The prevalence of metabolic syndrome as a complex of cardiometabolic risk factors depends on the phenotype of the disease and is the highest in the LADA2 phenotype (about 90\%), which indicates that patients with this form belong to the group of high cardiovascular risk.

3. In order to assess the risk of cardiometabolic complications in patients with LADA it is recommended to establish its phenotype. The presence of the LADA2 phenotype indicates a high risk of metabolic and cardiovascular disorders.

4. Components of the metabolic syndrome in latent autoimmune diabetes in adults by the degree of manifestation of pathological changes occupy intermediate positions between classical type 1 and type 2 diabetes mellitus, depend on the degree of autoimmunity and insulin resistance and are most significant in LADA2-phenotype.

\section{References}

1. IDF Diabetes Atlas 9th ed. 2019. Available from: https:// diabetesatlas.org/en/resources.

2. Ahlqvist E, Storm P, Käräjämäki A, Martinell M, Dorkhan $\mathrm{M}$, Carlsson A, et al. Novel subgroups of adult-onset diabetes and their association with outcomes: a data-driven cluster analysis of six variables. Lancet Diabetes Endocrinol. 2018;6(5):361-69. DOI: 10.1016/S2213-8587(18)30051-2.

3. Andersen MK. New Insights into the Genetics of Latent Autoimmune Diabetes in Adults. Curr Diab Rep. 2020;20(9):43. DOI: 10.1007/s11892-020-01330-y.

4. Cervin C, Lyssenko V, Bakhtadze E, Lindholm E, Nilsson $\mathrm{P}$, Tuomi T, et al. Genetic similari-ties between latent autoimmune diabetes in adults, type 1 diabetes, and type 2 diabetes. Diabetes. 2008 May;57(5):1433-7. DOI: 10.2337/ db07-0299.

5. Carlsson S. Etiology and Pathogenesis of Latent Autoimmune Diabetes in Adults (LADA) Compared to Type 2 Diabetes. Front Physiol. 2019;10:320. DOI: 10.3389/fphys.2019.00320.

6. American Diabetes Association. 2. Classification and Diagnosis of Diabetes: Standards of Medical Care in Diabetes-2021. Diabetes Care. 2021 Jan;44(Suppl 1):S15-S33. DOI: 10.2337/dc21-S002.

7. Hawa MI, Kolb H, Schloot N, Beyan H, Paschou SA, Buzzetti $\mathrm{R}$, et al. Adult-onset autoimmune diabetes in Europe is prevalent with a broad clinical phenotype: Action LADA 7. Diabetes Care. 2013;36(4):908-13. DOI: 10.2337/dc12-0931.

8. Pozzilli P, Pieralice S. Latent Autoimmune Diabetes in Adults: Current Status and New Horizons. Endocrinol Metab (Seoul). 2018 Jun;33(2):147-59. DOI: 10.3803/EnM.2018.33.2.147.

9. Turner R, Stratton I, Horton V, Manley S, Zimmet P, Mackay IR, et al. UKPDS 25: autoanti-bodies to islet-cell cytoplasm and glutamic acid decarboxylase for prediction of insulin requirement 
Original research

in type 2 diabetes. Lancet. 1997;350(9087):1288-93. DOI: 10.1016/ s0140-6736(97)03062-6.

10. Pashkovs'ka NV. Latentnyi avtoimunnyi diabet u doroslykh (LADA): suchasnyi pohliad na problem [Latent autoimmune diabetes in adults (LADA): a modern view of the problem]. Mizhnarodnyi endokrynolohichnyi zhurnal. 2019;15(3):272-80. DOI: 10.22141/22240721.15.3.2019.172116.

11. Buzzetti R, Tuomi T, Mauricio D, Pietropaolo M, Zhou Z, Pozzilli P, et al. Management of Latent Autoimmune Diabetes in Adults: A Consensus Statement From an International Expert Panel. Diabetes. 2020;69(10):2037-47. DOI: 10.2337/dbi20-0017.

12. Hjort R, Ahlqvist E, Carlsson PO, Grill V, Groop L, Martinell $\mathrm{M}$, et al. Overweight, obesity and the risk of LADA: results from a Swedish case-control study and the Norwegian HUNT Study. Diabetologia. 2018;61(6):1333-43. DOI: 10.1007/s00125-018-4596-0.

13. Li X, Huang G, Yan X, Yang L, Zhou ZG. [Relation between insulin resistance and glutamic acid decarboxylase antibody titers in latent autoimmune diabetes in adults]. Nan Fang Yi Ke Da Xue Xue
Bao. 2010;30(6):1247-9.

14. Li X, Cao C, Tang X, Yan X, Zhou H, Liu J, et al. Prevalence of Metabolic Syndrome and Its Determinants in Newly-Diagnosed Adult-Onset Diabetes in China: A Multi-Center, Cross-Sectional Survey. Front Endocrinol (Lausanne). 2019;10:661. DOI: 10.3389/ fendo.2019.00661.

15. Hawa MI, Thivolet C, Mauricio D, Alemanno I, Cipponeri E, Collier D, et al. Metabolic syndrome and autoimmune diabetes: action LADA 3. Diabetes Care. 2009;32(1):160-64. DOI: 10.2337/dc08-1419.

16. Yang L, Liu X, Liang H, Cheng Y, Huang G, Zhou Z. Pathophysiological characteristics in patients with latent autoimmune diabetes in adults using clamp tests: evidence of a continuous disease spectrum of diabetes. Acta Diabetol. 2019;56(11):1217-24. DOI: 10.1007/s00592-019-01387-6.

17. Fourlanos S, Dotta F, Greenbaum CJ, Palmer JP, Rolandsson $\mathrm{O}$, Colman PG, et al. Latent autoim $\neg$ mune diabetes in adults (LADA) should be less latent. Diabetologia. 2005;48(11):2206-12. DOI: 10.1007/s00125-005-1960-7.

\section{Information about the authors}

Iryna Tsaryk - PhD student at the Department of Clinical Immunology, Allergology and Endocrinology, Bukovinian State Medical University, Chernivtsi, Ukraine.

Nataliia Pashkovska - MD, Professor, Head of the Department of Clinical Immunology, Allergology and Endocrinology, Bukovinian State Medical University, Chernivtsi, Ukraine.

Olga Ilashchuk - 4th year student, Bukovinian State Medical University, Chernivtsi, Ukraine.

Відомості про авторів

Царик Ірина Олександрівна - аспірант кафедри клінічної імунології, алергології та ендокринології, Буковинський державний медичний університет, м. Чернівці, Україна.

Пашковська Наталія Вікторівна - д-р. мед. наук, проф., зав. кафедри клінічної імунології, алергології та ендокринології, Буковинський державний медичний університет, м. Чернівці, Україна.

Ілащук Ольга Ігорівна - студентка 4-го курсу, Буковинський державний медичний університет, м. Чернівці, Україна.

\section{Сведения об авторах}

Царик Ирина Александровна - аспирант кафедры клинической иммунологии, аллергологии и эндокринологии, Буковинский государственный медицинский университет, г. Черновцы, Украина.

Пашковская Наталия Викторовна - д-р. мед. наук, проф., зав. кафедрой клинической иммунологии, аллергологии и эндокринологии, Буковинский государственный медицинский университет, г. Черновцы, Украина.

Илащук Ольга Игоревна - студентка 4-го курса, Буковинский государственный медицинский университет, г. Черновцы, Украина.

Надійила до редакції 19.05.2021

Рецензент - д-р мед. наук Присяэнюк В.П. (C) І.О. Царик, Н.В. Пашковська, О.І. Ілащук, 2021 